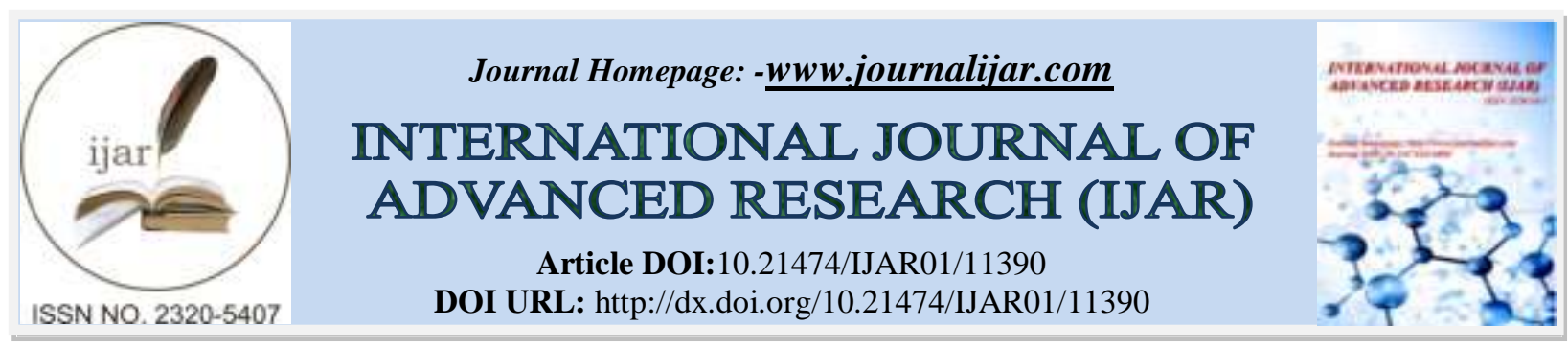

RESEARCH ARTICLE

\title{
EXPLOITATION OF SMALL ISLAND FOREST RESOURCES IN THE REGIONALAUTONOMY PERSPECTIVE IN MALUKU PROVINCE
}

Jenny Kristiana Matuankotta and Eric Stenly Holle

Lecturer at the Faculty of Law Pattimura University, Ambon.

\section{Manuscript Info}

(.........................

Manuscript History

Received: 25 May 2020

Final Accepted: 28 June 2020

Published: July 2020

Key words:-

Small Islands, Exploitation of Forest

Resources

\begin{abstract}
The small islands in Maluku Province have enormous and strategic potential for social, cultural, economic and environmental development and buffer people's sovereignty. These small islands have unique and distinctive characters such as biophysics, geography, inhabitants, culture and carrying capacity of the environment. This area provides productive natural resources, one of which is forest resources. However, the reality of exploiting the forest resources of small islands in Maluku is still not optimal, making it vulnerable to environmental damage that impacts on society and ecosystems. Therefore management and operations need to be done in a different format from other regional areas, especially those on the mainland which favor the community fairly, evenly while taking into account the sustainability of ecological, social, cultural and economic functions that are priorities main in the paradigm of community-based forest resource exploitation development.
\end{abstract}

Copy Right, IJAR, 2020,. All rights reserved.

\section{Introduction:-}

Small islands in Indonesia are part of the natural resources bestowed by God Almighty and constitute wealth controlled by the state and must be preserved to be able to be utilized for the greatest prosperity of the people both intergeneration and intergeneration in a sustainable manner. As part of natural resources, small islands have enormous and strategic potential for social, cultural, economic and environmental development and buffer people's sovereignty. This area provides productive natural resources such as coral reefs, seagrass beds, natural forests, mangrove forests, fisheries and conservation areas. Small islands also provide great environmental services because of the natural beauty they have that can drive the marine tourism industry.

This strategic significance is reflected in the objective conditions in Indonesia's territory which is the largest archipelagic state in the world. The affirmation of Indonesia as an archipelago is stated in the 1945 Constitution Article 25A. Indonesia's sea area covers an area of 5.8 million $\mathrm{km}^{2}$ with a total of 17,508 islands. The coastline length reaches $81,000 \mathrm{~km}$ with the second longest status in the world after the country of Canada and has the longest tropical beach in the world. The sea area is 5.8 million $\mathrm{km}^{2}$ or three times the land area, 37 percent of the world's species is in Indonesia. Petroleum and natural gas reserves are located along the islands of Sumatra, West Java, East Kalimantan, Maluku and Papua. While the largest forest products come from Kalimantan, Papua, Sulawesi and Sumatra. The configuration of such a large number of islands turned out to be mostly small islands with an estimated number of more than 10,000 island. 
The utilization of the potential of small islands in Indonesia is still not optimal due to the attention and government policies that have been more oriented towards land development. The development of small islands is a process that will bring a change to the ecosystem, social culture and politics. These changes will have an impact on the environment, socio-cultural life of the people that is unique and distinctive, economic and even the political policies of the outer small islands bordering directly with other countries. The higher the intensitymanagement and development carried out means the higher the level of resource utilization, the higher the environmental, sociocultural, economic and political changes that will occur in the area of small islands.

Maluku Province is the largest archipelago in Indonesia due to the condition of one region separated by the sea which is divided into several groups of large and small islands. The island group is a regional pattern in Maluku Province which is divided according to the physical condition of the region which is an archipelago with the aim of creating an optimal and efficient pattern, as well as an even distribution of services in living facilities. Maluku is often dubbed the province of a thousand islands, because its land area is dominated by small islands. The number of islands in Maluku in 2006 was based on the identification of satellite images of Lapan 1,412 units, while in 2020 the number of islands in Maluku experienced a decline of 1,392 units. The area of islands in Maluku ranges from approximately $761-18,625 \mathrm{~km}^{2}$. Islands with an area of less than 1 million hectare are categorized as small islands. With these criteria, only Seram Island with an area of 1.86 million hectare does not include a small island. In addition to Seram Island, other islands that have a larger area compared to other small islands are islands with an area of 1.86 million hectare which are not included as small islands. In addition to Seram Island, other islands that have a larger area compared to other small islands are Yamdena, Buru, Wokam, Kobrour and Trangan islands. The rest are small islands and even remote.

The small islands in Maluku Province have unique and distinctive characteristics both in terms of biophysics, geography, inhabitants, culture and carrying capacity of the environment. Therefore management and operations need to be done in a different format from other regional areas, especially those on the mainland with a vision that is always in favor of the interests of the community in a fair, equitable manner while paying attention to the sustainability of ecological, socio-cultural and economic functions. which becomes the first priority in the development paradigm of exploiting natural resources to achieve the full welfare of the community, in accordance with the mandate of Article 33 paragraph (3) of the 1945 Constitution that the Earth, water and natural resources contained therein are controlled by the state and used as much as possible for the prosperity of the people.

The formulation of "the right to control the state" is an instrument (instrumental) whereas "the maximum use of the prosperity of the people" is an objective (objectivies). The people referred to in this paper are aimed more at the people who live in/around the forest, including customary law communities who are directly affected by various corporate expansions that carry out activities of managing and exploiting natural resources, including forests on small islands which pay less attention to forestry developmentand sustainable.

Forest is one of the natural resources which has great potential value from various aspects. From an economic aspect, forests have a role as capital economic growth (resouces based economy) for increasing the country's foreign exchange, and local revenue so that development in the region should also be developed and developing if the management and business is carried out properly and controlled. From the socio-cultural aspect, the forest is a home for the community especially the customary law community who have occupied it for generations to build relationships with nature while continuing to carry out patterns of management and preservation of forest resources traditionally based on local wisdom owned such as gathering, hunting and performing rituals. traditional rituals. From the ecological aspect, the forest is home to a variety of flora and fauna riches and supports the lives of all living things on earth.

The principles of management and exploitation of forest resources today have undergone a fundamental change. The basic principles of the management and exploitation of state-based forest management through various policies and laws and regulations have proven to have caused various crises in the forestry sector that ultimately threaten the preservation of forest resources and the existence of indigenous and tribal peoples in small islands. as an entity that has special size, characteristics and vulnerability. The basic principle of the management and exploitation of statebased forest resources conceptually gives enormous authority and dominance of the state to regulate and control every forest management and exploitation activity. This principle also tends to make the forest as an economic unit for short-term benefits with rigid planning. In operationalizing activities usually characterized by a forest 
management system that is centralistic, top down and uniform. This reflects the view of development based on economic growth.

The limitation of authority granted to the regions to manage and utilize forest resources based on the principle of regional autonomy since the enactment of Law Number 23 of 2014 concerning Regional Government which gives authority in the forestry sector is only owned by the central government and the provincial government based on Article 14 of Law Number 23 Paragraph (1) emphasizes that: "The Administration of Government Affairs in the fields of forestry, maritime affairs, as well as energy and mineral resources are shared between the Central Government and the provincial regions". The formulation of the article indicates that the weakening of the position of the regional government in this case the Regency / City which gave rise to a smaller authority in the management of forest resources while that authority intersected with the rights and authority of the customary law community over forest resources. In addition, Law Number 41 of 1999 concerning Forestry and its derivatives is still centralized and does not favor the environment and the community.

Law Number 27 of 2007 concerning Management of Coastal Areas and Small Islands as constitutional basis specifically regulates the management of small islands for various activities. Article 23 paragraph (4) of Law Number 27 Year 2007 concerning Management of Coastal Areas and Small Islands indicates that the Concession Rights of Coastal Waters (HP-3) seems to be the only legal institution related to the utilization of small islands, both on land and waters. But on the other hand Law Number27 of 2007 does not specifically regulate the management and exploitation of forest resources while the exploitation activities carried out by forest utilization permit holders / Forest Concession Rights are mostly carried out on small islands that have their own vulnerabilities. This can lead to problems related to forests which have been regulated in forestry laws and implementing regulations.

The facts above show that there are serious problems not only from the ecological, economic and political aspects but also the marginalization of the community in terms of authority, participation and distribution of benefits from forest exploitation. On that basis, it is very necessary to change the paradigm of forestry development that is more focused on the management system and the utilization of forest resources that are based on the community or Community Based Natural Resource Management in the exploitation of forest resources carried out by legal subjects, namely holders of forest utilization business licenses ( Forest Concession) which aims to reduce poverty, conserve natural resources and good governance, thus the concept of sustainable and equitable forestry development includes environmental, economic, socio-cultural, political aspects anda balance between exploitation and conservation of valuable components of ecosystems that can be accommodated and can be accommodated well implemented supported by good governance patterns.

Based on the background of the above thought, then the problem formulation in this paper is how the concept of Community Based Natural Resource Management in the exploitation of forest resources can realize community welfare in Maluku Province as an archipelago based on the principle of regional autonomy?

\section{Research methods:-}

In accordance with the problem and title of this research, the type of research used is normative legal research, which is a study that mainly examines positive legal provisions, legal principles, legal principles and legal doctrines in order to address the legal issues encountered. This study uses two approaches namely the statutory approach that examines various legal bases both legislation products and regulations related to exploitation of forest resources in the islands and the second approach is a concept approach related to the problem being examined

\section{Discussion:-}

\section{Characteristics and Important Meaning of Concession of Small Islands:}

The definition or understanding of small islands is very diverse and has experienced debates among experts in various forums. The operational definition of small islands in Indonesia is still a thought of policy makers and experts related to this discipline. The agreement contained in Agenda 21 Indonesia gives an understanding of the island as a land surrounded by water, but at timeswhen the land is covered by water. The definition of island in article 121.1 of UNCLOS 1982 states that "an island is naturally formed area of land, surrounded by water, which is above water at hight tide".Based on this understanding, what is meant by an island is a land area that is naturally formed, surrounded by water and always above water at high tide. This understanding is still general, covering both large and small islands. While the small island has not been regulated in a standard rule regarding the limitation of its 
meaning and criteria both nationally and internationally. However, according to Dahuri, there is a general agreement that what is meant by a small island is a small island that is ecologically separated from its mainland and has a definite boundary, isolated from other habitats.

From the perspective of humanities called small islands, namely islands whose inhabitants are considered native to the island. Whereas the definition of small islands in the Interoceanic Workshop on Sustainable Development and Environmental Management of Small Island in 1986 was based on the area and population, namely the area of money has an area of $10,000 \mathrm{~km}^{2}$ or less with a population of less than 500,000 inhabitants. In fact it turns out that many islands measuring between $1000-2000 \mathrm{~km}^{2}$ have the same characteristics and problems as islands less than $1000 \mathrm{~km}^{2}$ in size, so it was decided by UNESCO (1991) that the small island is a small island with an area of less than $2000 \mathrm{~km}^{2}$.

If small island boundaries are based on socio-economic and demographic utilization, small island uses with a size of $2000 \mathrm{~km}^{2}$ should be based on conservation. If it rests on the conservation function, only about 50 of the small island area can be utilized for various socio-economic and demographic uses. In the legislation, limits on the understanding and criteria of small islands can be referred to in Article 1 number (3) of Law Number 27 of 2007 concerning Management of Coastal Areas and Small Islands jo Government Regulation Number 62 of 2010 concerning Utilization of Islands Outermost Small Island Article 1 number (3) which states that a small island is an island with an area of less than or equal to $2,000 \mathrm{~km}^{2}$ (two thousand square kilometers) and its ecosystem unity. The definition of small island is also mentioned the same in Maluku Province Regional Regulation Number 1 of 2008 concerning Zoning Plan for Coastal Areas and Small Islands of Maluku Province 2018-2038.

As the largest archipelago in the world, Indonesia has the natural resources of small islands that are very large and diverse. Small islands which physically possess abundant marine resources, are a nation's strategic assets to be developed on the basis of the use of marine resources and environmental services. These lam resources in the future will increasingly play an important role. This is related to the growing number of Indonesia's population and the potential of Indonesia as an archipelago that has thousands of small islands.

Small islands provide a variety of productive natural resources such as mangrove ecosystems, seagrass ecosystems and coral reefs along with other marine biota, recreation / tourism areas, conservation and other types of utilization. Small islands are a special case of development, because they have special characteristics that include natural resources, economics, specific socio-cultural aspects, small islands have the potential to be developed while taking into account the principles of sustainable development both ecologically and economically. From the economic aspect, the area of small islands as one of the marine resources has a great opportunity to develop potential business based on resources (resource-based industry) such as the fishing industry, tourism, processed industries and other industries that are environmentally friendly.

However, so far the coastal areas and small islands have not received a significant development touch because national development in the past was more land-oriented. Although there are development activities, but more consider economic growth, so that less attention to environmental sustainability and even often marginalize the local community. The management of small islands is very important and strategic for several reasons, namely: First, small islands are one of the areas that have high biological productivity. The most productive ecosystems in the world, such as natural forests that have a variety of unique and unique types of flora and fauna, mangrove forests, seagrass beds and coral reefs grow and develop in coastal areas and small islands. Second, many small islands have beautiful and comfortable areas for tourism and recreation, meanwhile small islands also become centers of settlements, ports and other human activities, third, small islands generally experience environmental pressures is high, due to population density and high development internality in the region. In addition, environmental impacts stem from development activities on small islands such as the exploitation of forest resources carried out by corporations. Fourth, small islands, especially coastal areas, are common property resources. That is, anyone can use this region for various purposes. So it is susceptible to conflict development and limited access to use of these areas so it needs to be managed properly so that the impact of human activities can be controlled and maintained for conservation.

The importance of small islands can be seen from three functions: security, economic and ecological functions. From the point of view of defense and security, small islands, especially on the border, have an important meaning as a gateway to the entry and flow of people and goods, for example in Sabang, Sebatik and Batam which are also 
vulnerable to smuggling of illegal goods, narcotics and illegal drugs. From an economic aspect, the area of small islands has a great opportunity to be developed as an area of potential business based on resources (resource-based industry) that is environmentally friendly. In addition, small islands can also be used and developed to support regional growth. Ecologically, coastal ecosystems and small islands function as regulators of the global climate, hydrological and bio-geochemical cycles, absorbing waste, alternative energy sources and other support systems.

Based on these conditions, the goals and objectives of small island development are economically, small island development is able to provide benefits for all economic actors and economic growth, socially providing guarantees for improving the welfare of the community, ecologically preserving resources and resources support the environment, politically able to create a conducive climate for the sustainable exploitation of small island resources and for the strengthening of national unity.

\section{Issues and Problems in the Development of Small Islands: Global Issues:}

Some international conventions are the basis for the management and management of small islands such as conventions relating to the protection of certain species, the establishment of restricted areas and / or restricted areas, pollution control laws due to sea transportation and others. The results of the Earth Summit at Rio Janero, Brazil in 1992 produced several important documents including: Rio Principles, Climate Change Convention and Biodiversity Convention, Forestry Principles and Agenda 21. Some priority issues requiring special attention are climate change and rising sea levels, natural disasters and environmental damage, clean water resources, coastal ecosystems, coral reefs and forest resources, renewable energy sources and tourism to protect the environment and culture.

\section{Regional Issues:}

Management and exploitation of small islands that pay less attention to environmental aspects and are related to other regions in the regional scope, for example sand mining activities at sea can affect the existence of adverse bases in setting maritime boundaries with neighboring countries, exploitation of forest resources by burning forest land for uncontrolled land clearing can cause the disappearance of small islands. With the entry into force of the ASEAN and Asia Pacific free market and increased sub-regional economic cooperation will spur the development of small islands, especially in investment activities.

\section{National Issue:}

With the large number of islands and natural resource potentials and their scattered locations making it difficult to achieve them, the government should pay serious attention to national issues relating to small islands that are not accommodating data related to small islands that contain names, broad, potential, characteristics, business opportunities, problems and others, limited sources of sea transportation facilities and infrastructure that connect between islands, some of the small islands are underdeveloped and isolated areas and far from the main market, open to small-scale but sensitive economic systems to market shocks from outside on a larger scale, uninhabited or sparsely populated but have good natural resource potential but are limited and exploited without control and supervision, disputes between small islands between provinces and districts/cities, sensitive to natural disasters such as volcanism, earthquake and tsunami, occur this is pollution around the waters of small islands due to deforestation and sand mining, the unclear management authority in the border areas between the government, provincial / municipal governments, small islands has the potential to become a place of activity that can threaten national stability and security and still lack monitoring and supervision systems on small islands.

\section{Regional Issues:}

The implementation of regional autonomy based on Law Number 23 of 2014 concerning Regional Government has raised several issues in the management of small islands, especially in Maluku Province, namely: empowerment and enhancement of the role of regional and community institutions in the framework of managing small islands, pressure on resources natural resources and the environment in the context of increasing regional income, the availability of data, information and regulations needed in making policies related to the management of small islands, cooperation between regions in the management of small islands; in the field of security, resource use and environmental quality improvement, disputes between regions regarding ownership status and management authority of small islands. Besides having great potential, small islands in Maluku Province also have constraints such as community poverty and limited human resources, high development costs, low access to transportation and communication, environmental and resource degradation, limited basic infrastructure, very vulnerable and carrying capacity limited, weak supervision and law enforcement in conflict over the management of its natural resources. 


\section{Overview of the Islands Region in Maluku Province: Characteristics of the Maluku Islands Region:}

The main problem faced in the small island area is the understanding of the character of small islands which is still very limited and the development of knowledge related to small islands is not widely available. Regional infrastructure development tools and the concept of sectoral development, especially the concept of sustainable forest development, are still applied centrally, many show the concept of large islands and do not take into account the character and characteristics of small islands in Indonesia. As a result of this application, many problems have arisen in the area of small islands. Many potential natural resources on land and sea are destroyed. As an entity that has specific size, characteristics and vulnerability, management of small islands in Maluku requires a different format from other regional areas, especially those on mainland island.

Maluku Province has an area of 46,914.03 $\mathrm{km}^{2}$. Maluku Province consists of small islands which have unique characteristics in terms of biophysics, geography, inhabitants, culture and carrying capacity of the environment, among others; varying biogeophysical and socio-economic conditions of the community; has a large beach and ocean area; have interconnectedness and influence between the closest ecosystems; small islands with bumpy to mountainous topography form a narrow river basin that greatly influences the hydrological process; availability of clean water and ground water is limited; land area more affected by volcanic eruptions, earthquakes, tsunamis, landslides, and tropical cyclones / storms; the area is directly affected by the maritime climate; has a special environment with a high population of endemic species; most island territories are still isolated; most people are helpless, and more strongly bound by culture (customs); Local economic conditions encourage population migration to other areas which causes scarcity of quality human resources, in rural areas.

Forests in Maluku have various types of endemic flora and fauna, have high values and are preserved until now and provide many benefits to the community. In addition to having abundant natural resources, from the social and cultural aspects of Maluku it is also known for its unique and unique culture seen from a variety of traditional ceremonies or rituals, pela and gandong traditions, sasi traditions, etc. Customary law communities in Maluku in maintaining the functions, carrying capacity and sustainability of forest resources still uses its local wisdom. Likewise with the forests that are believed by the Maluku traditional law community as a home for their lives to live and earn a living. Place to carry out various activities to support economic, social, cultural and religious life such as hunting, gathering, performing traditional rituals and so on.

According to Farida Patittingi, the uniqueness of these small islands is actually a potential to be developed, because most of the small islands have natural resources and environmental services (environmental services) that are very potential for economic development. The potential possessed by these small islands is what attracts certain parties to take advantage of small islands, especially for economic interests.

The topographical conditions of the Maluku Islands include lowlands, hills and mountains. Regency / city areas with lowland topography namely West Southeast Maluku, Southeast Maluku, Central Maluku, West Seram, East Seram and Buru and South Buru. Specifically, the islands in the Maluku region are islands that are grouped together and have heterogeneous characteristics. The character that is different from one island to another is caused by differences in geographical, physical, climate, social, cultural and ethnic aspects and the stages of economic development in the region. The topography in Maluku Province is generally hilly along the coastline to the highlands, the characteristics of this region are influenced by the meeting of two earth plates called the Pacific and Mediterranean Circum. These characteristics make this region almost 70 percent consists of plateaus with varying heights.

Area of Forest Area in Maluku Province:

Area of Production Forest Area Based on the Minister of Environment and Forestry Decree Number 854 / Menhut-II / 2014 dated 29 September 2014 according to forest types in Maluku Province in 2019 consisting of 429,538 hectare of conservation forest, 627,256 hectare of protected forest, limited production forest of 894,258 hectare, permanent production forests 643,699 hectare, conversion production forests $1,324,866$ hectare, overall the total area of forest in Maluku reaches 3,919,617 hectare. The broadest land cover classification on Maluku Island is Secondary Dry Land Forest which reached 49.97 percent in 2014 and 51.82 percent in 2018 to the width of Maluku Island, the area increased by around 3.71 percent in that period. In the period of 2014-2018 the categories of land cover that experienced the greatest reduction were Primary Dry Land Forests, Open Land, Shrubs / Shrubs, Secondary Mangrove Forests, and Secondary Swamp Forests. On the other hand, land cover categories that were added in the 
2014-2018 period included secondary dry land forest, Savanna/pasture, dry land agriculture, shrub mixed dry land agriculture, and primary mangrove forest.

The companies holding forest utilization or HPH/HPHT permits in Maluku Province numbered 13 companies that were actively operating in 2020. Previously the Maluku Provincial Government had imposed a moratorium or temporary suspension of the operational activities of companies holding HPH/HPHT Permit permits based on the Maluku Governor's letter Number 552/1850 Year 2019 The reason is that the holder of the forest utilization permit (corporation) ignores the obligation to protect the environment and respect the existence of indigenous and tribal peoples, thus impacting on the destruction of the forest and the limited access of the indigenous and tribal peoples to their territory. The moratorium emphasizes that forest management concession holders must prioritize the principle of sustainability and ensure the sustainability of forest functions in the area being cultivated by carrying out activities in accordance with the principles of sustainabledevelopment.

\section{The concept of Community-Based Natural Resource Management in the exploitation of small island forest} resources in Maluku Province:

In general the area of small islands in Maluku Province has experienced the effects of climate change, such as rising sea water on small islands, rising temperatures and local impacts ranging from floods, landslides and prolonged drought. Forest destruction due to over-exploitation by companies without regard to the existence of indigenous peoples and their forest reserves and a number of companies that have operated so far have not provided benefits for the welfare of the community or local government.

The Maluku island area development approach uses three concepts, namely island cluster units, island sea area and multigate systems which aim to accelerate economic growth on these islands. Island Cluster is a regional pattern in Maluku Province divided according to the physical condition of the region which is an archipelago with the aim of creating an optimal and efficient pattern, as well as equality in the service of living facilities. In each task force in some areas it functions as an exit that seeks to become a center for economic growth, as well as a public service center and a center for trade and traffic in goods and services. With the concept of a group of islands, the sea area is not seen as a divisor but rather as a unifier that has strategic economic value.

In the author's view, the island development approach initiated by the local government is quite good, but in its implementation it is felt that it still lacks a significant impact, especially for equitable development in small island areas because until now there are still many people whose lives are marginalized and even economically poor, and the management and utilization of natural resources which have a lot of potential, especially forest resources as the main buffer for small islands, are increasingly damaged due to exploitation activities without considering their functions and carrying capacity. One reason is Law No. 41 of 1999 concerning Forestry and its operational regulations do not regulate the management and exploitation of forest resources in the area of small islands. Meanwhile in Law Number 27 of 2007 concerning Management of Coastal Areas and Small Islands.Article 23 paragraph (4) indicates that the Concession Rights of Coastal Waters (HP-3) seems to be the only legal institution related to the use of small islands, both on land and waters. While exploitation of forest resources should be carried out by the holder of a forest utilization permit or Forest Concession (HPH), this certainly has its own legal impact. Because the laws and regulations do not clearly regulate the management and exploitation of forest resources in small islands, the permit holders or HPH are free to exploit forests without any supervision and control, especially those small islands are far and remote so difficult to reach.

In terms of the distribution of governmental authority through the principle of regional autonomy in the management and utilization of forest resources, the authority of regencies/cities is limited and given to the central government and provincial governments based on Law Number 23 of 2014 concerning Regional Government. Article 14 of Law Number 23 Year 2014 Paragraph 1 confirms that: "The Implementation of Government Affairs in the fields of forestry, maritime affairs, as well as energy and mineral resources are shared between the Central Government and the provincial Regions". The formulation indicates that the concept of government development in the management and exploitation of natural resources including forests is still centralism and does not favor communities in the regions, especially in the area of small islands. State legitimacy in the context of control of forest resources contained in Law Number 41 of 1999 concerning forestry and its derivatives is centralistic (forcing, exclusive, hierarchical, systematic and uniformly applied) and applies from the top downward without regard to the top downward environmental sustainability and the existence of indigenous and tribal peoples even clearly ignore the applicable law, namely adat law and become one of the causes of prolonged conflict in the forestry sector between 
the government, holders of forest concessions with indigenous and tribal peoples so that they have several times been tested by the Constitutional Court. Whereas, as a social unit that obtains its own legitimacy based on culture and other surrounding communities, this social unit is a unit that understands the harmony between the community and the harmony between the community and the environment.

Of the various problems above, the authors offer the concept of Communitarian Based Natural Resource Management (CBNRM) in the exploitation of forest resources, especially on Small Islands, which emphasizes the role of the community in every process of exploiting forest resources carried out by companies or business permit holders. Forest. Community Based Natural Resource Management as an alternative to top-down strategies in natural resource management that are carried out collectively on ecosystem management to improve human welfare and achieve environmental and economic, social goals, and balance exploitation and conservation as a valuable component of ecosystems.

The concept of Community Based Natural Resource Management is "... an approach of natural resource management by, for and with local communities with the objectivity of improving livelihoods and security of local people, empowering them and enhancing conservation efforts". In principle, Community Based Natural Resource Management is an activity that emphasizes natural resource management by, for and with local communities. Community Based Natural Resource Management is a system of managing natural resources in a place, where the local community in that place is actively involved in the process of managing the natural resources contained therein. Management is multidimensional starting from the planning, implementation, and utilization of its results.

Community Based Natural Resource Management is very dependent on the participation of local communities. The main objective of Communitarian Based Natural Resource Management as a process in which landholders (landowners) get access and use their rights to natural resources, collaborative and transparent planning and participate in the management of natural resources, as well as getting benefits both financially and non-financially for their involvement. This definition emphasizes aspects of access and involvement of actors in it. Landholders in this sense, including private, private and communal property. This definition implies the necessity of economic and political transfer, high-value resources such as wildlife or forestry, and change from centralized to community control. Thus the goal of Communitarian Based Natural Resource Management is that greater efficiency in natural resource management comes from local community knowledge, saves more costs and better decisions will be achieved through internalization of social and environmental costs. According to the authors, Community Based Natural Resource Management in the exploitation of forest resources on small islands contains several main things, namely:

\section{Community Empowerment:}

Exploitation of forest resources on small islands aims to increase financial benefits for both companies and state and local government revenues, but often exploitation of forest resources is carried out without regard to the community by involving the community in the process of forest exploitation and carrying out community empowerment activities so that community life who live on small islands still live in underdevelopment and underdevelopment so that the exploitation of forest resources by the state through concession licenses granted to corporations does not provide welfare for the community. In addition, most of the small islands, including areas that are densely populated but have very limited facilities and infrastructure, even the people are classified as poor. For this reason, the distribution and allocation of resources along with economic and social benefits must be based on the principles of fairness and balance of interest because the area of small islands has a great opportunity to be developed as a potential resource-based business area based on environmentally friendly.

\section{Conservation of natural resources:}

Community empowerment is closely related to the conservation of natural resources, this is because the customary law communities or local communities who inhabit forest areas on small islands whose lives depend on the results of natural resources for their livelihoods. Therefore, it is important for the state to conserve its natural resources through sustainable management and exploitation of natural resources, especially forests, which are granted concession licenses for companies. Thus the company's obligation to use appropriate technology, effective and environmentally friendly in the process of exploiting forest resources. In addition, conservation and protection of biodiversity and their habitats, including the preservation and recovery of priority, rare and threatened species, as well as threatened populations. 


\section{Good Governance:}

The involvement of indigenous and tribal peoples in the management and exploitation of forest resources needs to be achieved with the decentralization of authority over these resources. The existence of decentralization requires Good Governance in its management and operations. Decentralization in Community Based Natural Resource Management is carried out to a certain degree. Distribution of power, especially among local communities, including the transfer of authority from the central and regional governments to the local community and institutions, participation in decision making, distribution of supervision, and democratization.

\section{Conflict Resolution:}

In the management and exploitation of forest resources on small islands, there is usually a conflict between the government, companies and customary law communities / local communities. For that reason, conflict resolution and disputes over forest resources between local communities and between local, regional and national interests need to be carried out using a persuasive approach while taking into account national legal provisions balanced with applicable laws in the community (customary law) .

\section{Sustainable utilization:}

The exploitation of forest resources on small islands must be based on ecology, social and economy, in an effort to maintain their availability for a long time for present and future generations. Economically, the small island forest resources store a variety of potential biological resources are very large, ecologically it has been proven that small islands provide environmental services that are of high economic value that can be developed, socially culturally, island communities have a culture potential for development. The island community has its own knowledge system (indogenous knowledge) which is very valuable for the exploitation of forest resources. Islanders also have local wisdom which is very valuable for the conservation of forest resources. Besides that politically, small islands are a buffer of national sovereignty to maintain the existence of the integrity of the Indonesian state.

Sustainable development that is balanced and integrated between economic, socio-cultural, environmental and political aspects is the principle of development which is always the basis of development planning, especially regional development in areas that are geographically dominated by the sea, with the distribution of small islands that require special handling like Maluku Province. Integration of development planning requires synergy between sectors, between local governments and stakeholder involvement as a whole, starting from development planning, implementing planning, monitoringand controlling.

\section{Closing:}

The main component of the concept of Community Based Natural Resource Management in the exploitation of forest resources on small islands is the collective involvement between the government, entrepreneurs / holders of forest utilization business licenses and the community / customary law communities. The role of the state in this case the government in its policy in the field of forestry is more emphasis on empowerment and community participation in every exploitation of forest resources given to corporations, meanwhile the role of the permit holder / HPH in carrying out its various activities pays more attention to the carrying capacity and functions of the ecosystem as well as the existence of customary law communities. The role of indigenous and tribal peoples in the exploitation of forest resources by HPH is to supervise and play an active role in every process of exploiting forest resources. Thus the exploitation of forest resources on small islands must be supported by legislation that is able to regulate comprehensively and holistically about the various interests that exist in small islands, so that the economic, ecological, socio-cultural and political potential of the islands Small businesses can be a source of welfare for the community, so they can achieve the goals and objectives of developing small islands

\section{References:-}

1. Alex Retraubun, Prosiding SemiolokaPenentuan Definisi dan Pendataan Pulau-Pulau di Indonesia, Direktorat Pemberdayaan Pulau-Pulau Kecil, Direktorat Jenderal Pesisir dan Pulau-Pulau Kecil, Depertemen Kelautan dan Perikanan.

2. dan Sri Utami, Profil Pulau-Pulau Kecil di Indonesia, Jilid 1, Depertemen Kelautan dan Perikanan. Direktorat Jenderal Pesisir dan Pulau-Pulau Kecil, Direktorat Pemberdayaan Pulau-Pulau Kecil, Jakarta

3. Beller, S. William, Proceedings of The Interoceanic Workshop on Sustainable Development and Environmental Management of Small Island, US Man and The Biosphere Program. United States Depertemen of State, Humaco, Puerto Rico. 
4. D'Ayala, and P Hein, Sustainable Development and Environment Management of Small Island. Unesco and the Parthenan Publishing Group, Great Britain.

5. Bengen, Dietriech G, Definisi, Batasan dan Realitas Pulau-Pulau Kecil. Makalah, Semiloka penentuan Definisi dan Pendataan Pulau di Indonesia, Jakarta

6. Bambang Daru Nugroho, Hukum Adat, Hak Menguasai Negara Atas Sumber Daya Kehutanan dan Perlindungan Terhadap Masyarakat Hukum Adat, Rafika Aditama, Cet I, Bandung 2015.

7. Child B, Lyman MW, Natural Resources and Community Assets, Lessons From Two Continents. Sand County Foundation And The Aspen Institute, Madison/Washington DC,2005

8. Eric Stenly Holle, Abrar Saleng, Aminuddin Sale, Suriyaman Mustari Pide, Nature of Exploitation of Forest Resources Towards the Welfare of the Customary Law Community in Maluku Province (Perspectives on Pancasila Law and Legal Pluralism), Journal of Law, Policy and Globalization,Vol.94, International Institute for Science, Technology and Education, 2020

9. Farida Patittingi, Dimensi Hukum Pulai-Pulau Kecil di Indonesia, Mahakarya Rangkang Offset, Yogyakarta, 2012

10. Jay Ram Adhikari, Communnity Based Natural Resource Management in Nepal With reference to Communitu Forestry: A Gender Perspective. Journal of The Environment, Vol. 6 No. 7. 2001, Ministry of Population and Environmental, 2001

11. Jenny KristianaMatuankotta, PengakuandanPerlindunganHukumTerhadapEksistensiPemerintahanAdat, Jurnal SASI Vol. 26 Nomor 2, April - Juni 2020 - http//fhukum.unpatti.ac.id/jurnal/sasi/issue/view/14

12. P.A. Titaley, Kebijakan Revitalisasi Pertanian di Maluku, Sagu Dalam Revitalisasi Pertanian Maluku, Makalah, Bappeda Maluku dan Unpatti

13. Peter Mahfud Marzuki, Penelitian Hukum, Prenada Media, Cet. I, Jakarta, 2005

14. Rohmin Dahuri, Pendekatan Ekonomi-Ekologis Pembangunan Pulau-Pulau Kecil Berkelanjutan, Makalah Seminar Nasional Pengelolaan Pulau-Pulau Kecil di Indonesia, Jakarta 1998

15. Badan Pusat Statistik, Provinsi Maluku Dalam Angka, 2020

16. Badan Pusat Statistik, Sistem Terintegrasi Neraca Lingkungan dan Ekonomi Indonesia (Katalog) 2014-1018. 